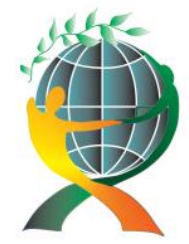

\author{
(online) $=$ ISSN $2285-3642$ \\ ISSN-L = 2285 - 3642 \\ Journal of Economic Development, Environment and People \\ Volume 2, Issue 2, 2013 \\ URL: http://jedep.spiruharet.ro \\ e-mail: office jedep@spiruharet.ro
}

\title{
Monitoring of Sun's Uv Radiation and Stratospheric Ozone Layer Thickness over the Region of Novi Sad (Serbia)
}

\author{
Prof. Zoran Mijatović, PhD, R. Kobilarov, B. T. Vujičić, D. T. Mihailović \\ University of Novi Sad, Serbia
}

\begin{abstract}
.
The results of the Sun's UV radiation and stratospheric ozone layer thickness over the region of Novi Sad (Serbia) are reported. Monitoring the UV radiation and stratospheric ozone layer thickness started in 2003 and 2007 respectively. Results recorded during these years have been analyzed. Upon these analyses it can be concluded that during observational period, the significant difference in daily maxima of the UV radiation recordings or ozone seasonal maximal values from year to year, has not been detected. Obtained results are graphically depicted.
\end{abstract}

Keywords: Solar radiation, UV radiation, UV monitoring, Ozone layer

JEL Codes: Q53, Q54

\section{Introduction}

Sun, the closest star to our planet, emits electromagnetic radiation in a wide range spectrum. This radiation is called Sun's or solar radiation. Part of the radiation is emitted in ultraviolet (UV) wavelength range below $400 \mathrm{~nm}$ (CIE - Commission Internationale de I'Eclairage definition). The great amount of this radiation is absorbed, reflected or scattered by the Earth's atmosphere. Particularly important role in the absorption has the stratospheric ozone (O3 molecule) layer where UV radiation is mostly absorbed. This layer completely absorbs radiation of wavelengths below $280 \mathrm{~nm}$, so called UV-C radiation which has germicidal effect, i.e. kills bacteria. The radiation in the wavelength range $280-400 \mathrm{~nm}$ (UV-B, $280-320 \mathrm{~nm}$ and UV-A, $320-400 \mathrm{~nm}$ ) is partly absorbed. Amount of the absorbed radiation strongly depends on ozone layer thickness. Namely, the amount of absorbed radiation is getting higher when ozone layer thickness goes up.

Besides useful effects, the UV radiation has harmful effects on humans, plants, animals and ecosystem. UV-B is typically the most destructive form of UV radiation because it has enough energy to cause photochemical damage to cellular DNA. UV- Bis needed by humans for synthesis of vitamin D; however, harmful effects can include erythema (sunburn), cataracts, and development of skin cancer (melanoma). UV$A$ is the most commonly encountered type of UV light. UV-A exposure has an initial pigment-darkening effect (tanning) followed by erythema if the exposure is excessive. Atmospheric ozone absorbs very little of this part of the UV spectrum. UV-A is needed by humans for synthesis of vitamin D; however, overexposure to UV-A has been associated with toughening of the skin, suppression of the immune system, and cataract formation. These risks increase with the increasing of UV radiation intensity (radiation flux expressed in SI 


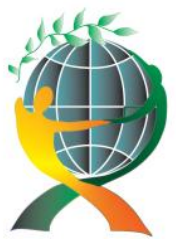

\author{
(online) $=$ ISSN $2285-3642$ \\ ISSN-L = $2285-3642$ \\ Journal of Economic Development, Environment and People \\ Volume 2, Issue 2, 2013 \\ URL: http://jedep.spiruharet.ro \\ e-mail: office jedep@spiruharet.ro
}

units $\mathrm{W} / \mathrm{m} 2$ ). Therefore ozone layer, and its thickness, is very important as the shield from intensive UV radiation. Ozone in stratosphere is produced by the action of UV radiation, but it is also destroyed by this radiation. The production and destruction are balanced. This process is known as Chapman cycle (Chapman, 1930). Unfortunately, human activities cause the emission of halogen source gases that contain chlorine and bromine atoms (Molina and Rowland, 1974; Rowland, 2010). These emissions into the atmosphere ultimately lead to stratospheric ozone depletion. These gases are called "chlorofluorocarbons", abbreviated as CFCs. CFCs, along with carbon tetrachloride $(\mathrm{CCl} 4)$ and methyl chloroform $(\mathrm{CH} 3 \mathrm{CCl} 3)$ are the most important chlorine-containing gases that are emitted by human activities and destroy stratospheric ozone. The first decreases in Antarctic ozone were observed in the early 1980s. On 1985, a treaty called the Convention for the Protection of the Ozone Layer was signed in Vienna. This was followed by the Montreal Protocol on Substances that deplete the Ozone Layer, signed in 1987 and ratified in 1989. The protocol established legally binding controls for developed and developing countries on the production and consumption of halogen source gases. Later, The Montreal Protocol was strengthened with various Amendments and Adjustments.

Increasing public concern over declining ozone levels and the resultant UV radiation reaching the Earth has brought the world-wide ozone and the UV radiation networks and also a need to communicate daily information about UV radiation level to the public in a credible and understandable manner. This standard establishes a quantitative index for reporting the level of harmful ambient solar ultraviolet radiation reaching the surface of the Earth to the general public. The Global Solar UV Index quantifies the exposure of the skin to ultraviolet radiation. UV index (accordingly to World Meteorological Organization - WMO) is defined as (WMO, 1994): Where the above integral is expressed in $\mathrm{W} / \mathrm{m} 2$. is the global spectral irradiance and is the action spectrum for erytema proposed by CIE and defined by McKinley and Diffey (1987).

The Dobson Unit (DU) is the most common unit for measuring ozone concentration. The unit is named after G. M. B. Dobson, who designed the 'Dobson Spectrometer' - the standard instrument used to measure ozone from the ground. The Dobson spectrometer measures the intensity of the solar UV radiation at four wavelengths, two of which are absorbed by ozone and two of which are not. One Dobson Unit is the

$$
U V I=40 \int_{250 m m}^{400 \text { mm }} E_{G}(\lambda) \cdot C(\lambda) d \lambda
$$

number of molecules of the ozone that would be required to create a layer of pure ozone 0.01 millimeters thick at a temperature of $0 \mathrm{OC}$ and a pressure of 1 atmosphere (the air pressure at the surface of the Earth). Expressed another way, a column of air with an ozone concentration of 1 Dobson Unit would contain about 2.69x1016 ozone molecules for every square centimeter of area at the base of the column. Over the Earth's surface, the ozone layer's average thickness is about 300 Dobson Units or a layer that is 3 millimeters thick.

The next chapters contain description of the methods used for the monitoring of (i) the solar UV radiation and the measurement of ozone layer thickness, (ii) presentation of obtained results with discussion and finally (iii) conclusion. 


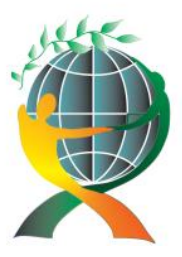

\author{
(online) $=$ ISSN $2285-3642$ \\ ISSN-L = $2285-3642$ \\ Journal of Economic Development, Environment and People \\ Volume 2, Issue 2, 2013
}

URL: http://jedep.spiruharet.ro

e-mail: office jedep@spiruharet.ro

\title{
2. Methods of measurement
}

Standard instrument that is used for monitoring of Solar UV radiation and ozone layer is spectral instrument known as Brewer spectrometer (WMO, TD 1066). Such instruments are very worth and are used usually for calibration procedure for broadband instruments and less sophisticated instruments for ozone layer monitoring.

Broadband instruments (WMO, 2008) are usually used to build up national Solar UV radiation monitoring networks. One of such instruments Yankee Environmental Systems (YES) UVB-1 piranometer is used for monitoring in this work. Relative spectral response (Dichter et al, 1993) of the instrument is close to erythemal action spectrum (McKinley and Diffey, 1987). Due to such spectral response in combination with the Solar spectrum, resulting measured quantity is very close to the integral value in Eq. (1). YES is placed inside the campus of the University of Novi Sad. Coordinates are $45.330 \mathrm{~N}, 19.850 \mathrm{E}$ and $84 \mathrm{~m}$ a.s.l. The instrument is connected to the computer for data acquisition via data logger. Measurements are done every $30 \mathrm{sec}$. These results are averaged for 10-min time interval and such obtained data, together with minimal and maximal data, are recorded in the daily data base. In the same time measured values are sent to the internet web page http://cmep.rs where are available to the public use every $10 \mathrm{~min}$. Measured values are presented numerically as well as graphically, by the means of diurnal course of UV index. As an example, this picture is presented in Fig. 1, for 24th May 2011, until 12.30 PM. As it can be seen from Figure 1 this day was partially cloudy.

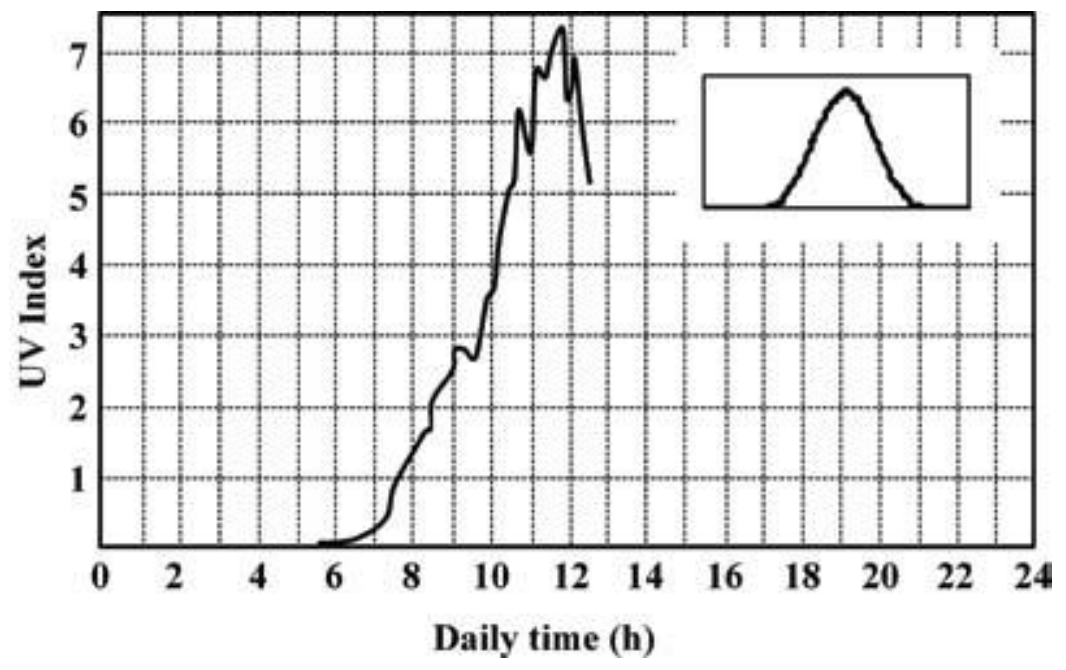

Fig 1: Diurnal course of the UV Index presented at web page http://cmep.rs

During cloudless days the curve presented in Figure 1 is a smooth curve, closely to the Gaussian one (illustrated in the rectangular of the upper right part of Figure 1). 


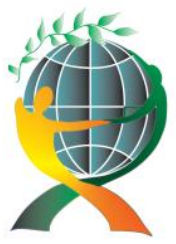

\author{
(online) $=$ ISSN $2285-3642$ \\ ISSN-L = $2285-3642$ \\ Journal of Economic Development, Environment and People \\ Volume 2, Issue 2, 2013
}

URL: http://jedep.spiruharet.ro

e-mail: office jedep@spiruharet.ro

For the monitoring of ozone layer thickness Microtops II, Solar Light Co. is used. The instrument is equipped with five accurately aligned optical collimators, capable of full field view of 2.50. Each channel is fitted with narrow-band interference filter and photodiode suitable for the particular wavelength. Short wavelengths of UV radiation are much more readily absorbed by ozone than the longer wavelengths in the same UV bandwidth. This means that the amount of ozone between observer and the Sun is proportional to the intensity ratio of two wavelengths of solar UV radiation. This instrument uses that relationship to derive the total ozone column (ozone layer thickness in DU) from measurements of three wavelengths $-305.0 \mathrm{~nm}$; $312.5 \mathrm{~nm}$ and $320.5 \mathrm{~nm}$. This principle is very similar to the traditional Dobson instrument. Two additional channels at $936 \mathrm{~nm}$ and $1020 \mathrm{~nm}$ are used for water column and aerosol optical thickness determinations. Measurements are possible only when Sun's disc is clearly visible, and the best results are obtained with the sun high in the sky. Complete description of the theory of operation is given in (Morys et al, 2001). Measurements are performed on every day, when is possible, around the noon. The scan length is about 20 sec with 32 samples in a scan. Each result that is stored in the data base is the average from at least five scans.

\title{
3. Results
}

Monitoring of solar UV radiation started in April 2003 and data are collected in the data base created for this purpose. This data base contains all measured values, so it is possible to retrieve data either for the particular day(s) and month(s) or year(s). Intensity of the solar UV radiation is highest during the summer, particularly at the end of June and beginning of July when maximal daily values reach UV Index of 9 or more. During the winter these values are at the yearly minimum when fall below 1 . Maximal daily values during the years 2003 - 2010 are presented in Figure 2. Data are missing for the period end of September 2006 beginning of May 2007 because the instrument was sent on recalibration.

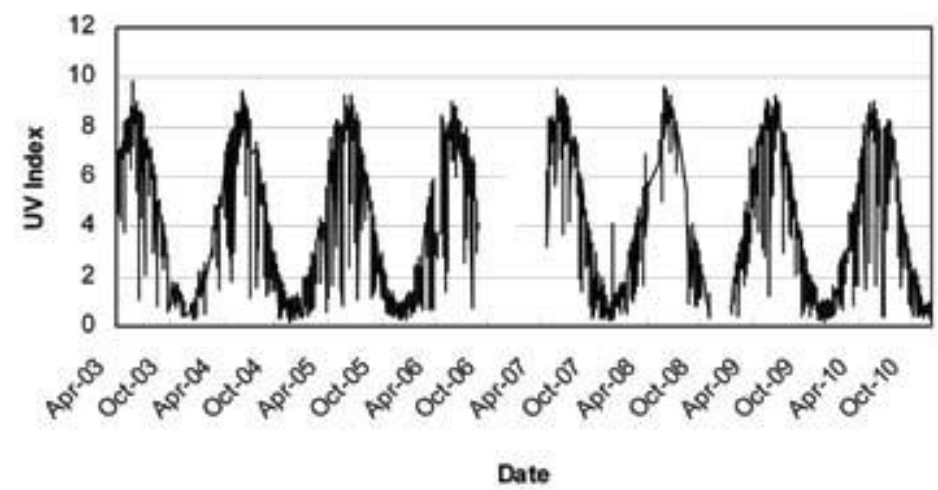

Fig. 2: Maximal daily values of the UV Index during the period $2003-2010$

Local minimums in the graph correspond to cloudy days. As it can be seen from Figure 2 maximal daily values of UV Index were registered during the summers. For these eight years maximal summer values are almost the same, around 9. Also the annual change of UV Index is the same from year to year. These facts 


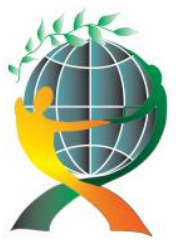

\author{
(online) $=$ ISSN $2285-3642$ \\ ISSN-L = $2285-3642$ \\ Journal of Economic Development, Environment and People \\ Volume 2, Issue 2, 2013 \\ URL: http://jedep.spiruharet.ro \\ e-mail: office jedep@spiruharet.ro
}

indicate that during observed period there were no significant changes in the atmospheric conditions having influence on the solar UV radiation.

Another quantity connected with the solar UV radiation is emitted dose, which is expressed in physical units Jm-2. The dose is a quantity which better indicates the possible influence of the UV radiation on different humans and others than simply intensity; because it takes into account not only intensity but also time of the exposure to the radiation. Consequently, it is possible that for the particular day maximal UV Index is very high, but the dose is very low. This is the case when the day is cloudy but cloudless around the noon.

The measured doses were $504647 \mathrm{Jm}-2,501866 \mathrm{Jm}-2,463315 \mathrm{Jm}-2,466487 \mathrm{Jm}-2,464245 \mathrm{Jm}-2,528211$ Jm-2, $490914 \mathrm{Jm}-2$ and $445781 \mathrm{Jm}-2$ for the years 2003, 2004, 2005, 2006, 2007, 2008, 2009 and 2010 respectively. As it can be seen the differences are not too big and probably they are caused by different numbers of cloudy days. The average annual dose is $483 \mathrm{kJm}-2$ with standard deviation of $28 \mathrm{kJm}-2$.

Solar UV radiation is necessary for ozone production, so the ozone layer thickness is changing during the year in accordance with the changes of UV radiation intensity. Under normal circumstances this layer is maximal in March-May (400 - 450 DU) and is minimal in September-November (250 - 300 DU). Monitoring of ozone layer started in August 2007. The measurements are performed in University campus in Novi Sad.

Results of measured ozone layer thickness for the period August 2007 - May 2011 are presented in Figure 3. As it can be seen from this figure maximal values over the period of observation are inside mentioned limits $400-450 \mathrm{DU}$, and also minimal values.

The exception is the period November 2010 - December 2011 when values were between 180 DU and 250 DU. Values below 200 DU are considered as >>ozone hole $<$ so it be said that in that period ozone hole, or similar, appeared over the region of Novi Sad. In March 2011 ozone hole was detected over North Pole that is unusual since temperature in the stratosphere over North Pole rarely drops below -78 oC. Such low temperatures are needed for the formation of polar stratospheric clouds that cause ozone holes over poles (usually above South Pole). However, the observed amount of the ozone loss does not coincide with observed ozone hole over the North Pole. Consequently, cannot be explained by the influence of this appearance. UV Index in this part of the year is generally low, so increase of around $20 \%$, caused by ozone layer depletion, cannot be detected with the high confidence. Since the data about the ozone depleting substances are not available, any explanation cannot be given properly why ozone layer was depleted in mentioned period. 


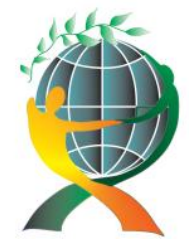

$$
\begin{gathered}
\text { (online) }=\text { ISSN } 2285-3642 \\
\text { ISSN-L }=2285-3642
\end{gathered}
$$

Journal of Economic Development, Environment and People

Volume 2, Issue 2, 2013

URL: http://jedep.spiruharet.ro e-mail: office jedep@spiruharet.ro

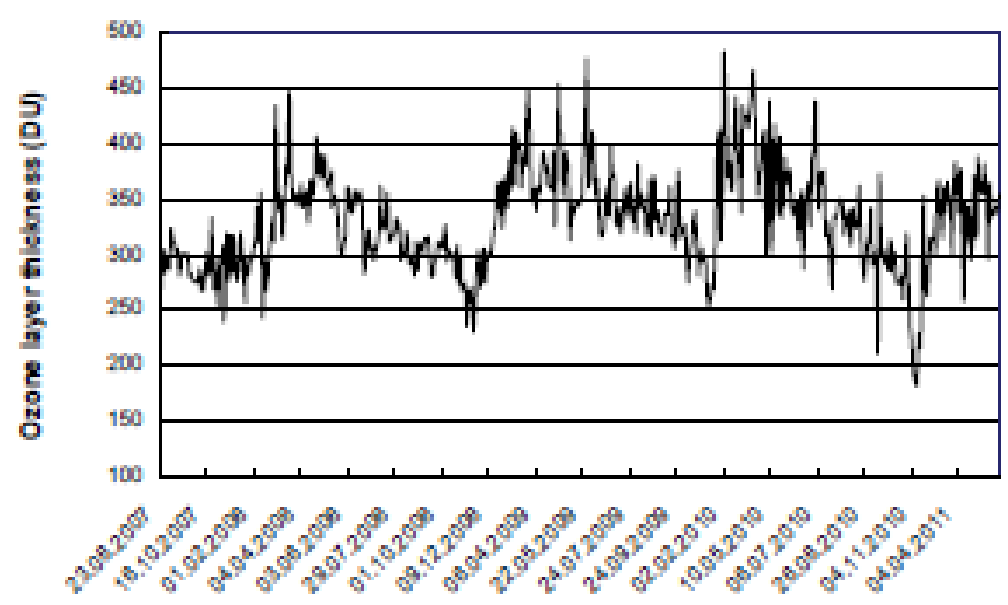

Fig 3: Measured ozone layer thicknes over the period 2007 - 2011.

\section{Conclusion}

The aim of this paper is to present activities and results of monitoring of solar UV radiation and ozone layer thickness in the region of Novi Sad (Serbia). In the first part short introduction about solar UV radiation, ozone layer and the units, is given. Next, methods applied for the measurements are described. Obtained results are presented and discussed. Concerning UV radiation it can be concluded that summer highs are almost the same over observed period. Similar conclusion can be drawn also for ozone layer thickness for seasonal changes with the exception of short period during the autumn 2010 when ozone layer thickness was unexpected. Appropriate explanation for this was not established.

\section{Acknowledgements}

This work is partially financed by City of Novi Sad, Directorate for Environmental Protection and by Republic Ministry of Education and Science within the framework of integrated and interdisciplinary research projects for the period 2011 - 2014 "Development of the methods, sensors and systems for monitoring quality of water, air and soil" (No. III 43008) and "Studying climate change and its influence on the environment: impacts, adaptation and mitigation" (No. III 43007).

\section{References}

[1] Chapman, S. (1930). A theory of upper-atmospheric ozone. Mem. Roy. Meteorol. Soc., 3, 103-125.

[2] Dichter, B. K., Beaubien A. F. and Beaubien D. J. (1993). Development and Characterization of a New Solar Ultraviolet-B Irradiance Detector. J. Atmos. Oceanic Technol., 10, 337-344.

[3] McKinley, A. F. and Diffey B. L. (1987). A reference action spectrum for ultraviolet induced erythema in human skin. CIE J., 6, 17-22. 


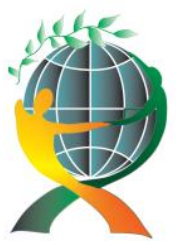

$$
\begin{gathered}
\qquad \begin{array}{c}
\text { (online) }=\text { ISSN 2285 - } 3642 \\
\text { ISSN-L }=2285-3642
\end{array} \\
\text { Journal of Economic Development, Environment and People } \\
\text { Volume 2, Issue 2, } 2013
\end{gathered}
$$

URL: http://jedep.spiruharet.ro

e-mail: office jedep@spiruharet.ro

[4] Molina J. M. and Rowland F. S. (1974). Stratospheric Sink for Chlorofluoromethanes: Chlorine Atom-Catalysed Destruction of Ozone. Nature, 249, 810 -812.

[5] Morys M., Mims F. M. and Anderson S. E. (2001). Design, calibration and performance of MICROTOPS II hand-held ozonmeter, User's Guide, Solar Light Co., Oak Lane, USA.

[6] Rowland F. S. Stratospheric Ozone Depletion by Chlorofluorocarbons (Nobel Lecture). http://www.eoearth.org/profile/F.rowland (accessed 21 August 2010).

[7] WMO. Instruments to Measure Solar Ultraviolet Radiation, Part 1: Spectral Instruments, (WMO TD No. 1066)

[8] WMO. (1994), Report of the WMO meeting of experts on UVB measurements, data quality and standardisation of UV indices, (WMO TD No. 625).

[9] WMO. (2008) Instruments to Measure Solar Ultraviolet Radiation - Part 2: Broadband Instruments Measuring Erythemally Weighted Solar Irradiance, (WMO TD No. 1289). 